\title{
Cloning and Expression of a Rat Brain Interleukin-1 $\beta$-Converting Enzyme (ICE)-Related Protease (IRP) and Its Possible Role in Apoptosis of Cultured Cerebellar Granule Neurons
}

\author{
Binhui Ni, ${ }^{1,4}$ Xin Wu, ${ }^{1}$ Yansheng Du, ${ }^{1}$ Yuan Su, ${ }^{1}$ Elizabeth Hamilton-Byrd, ${ }^{1,3}$ Pamela K. Rockey, ${ }^{1}$ \\ Paul Rosteck Jr., ${ }^{1}$ Guy G. Poirier, ${ }^{2}$ and Steven M. Paul ${ }^{1,3,4}$ \\ 1 Lilly Research Laboratories, Eli Lilly and Company, Indianapolis, Indiana 46285, ${ }^{2}$ Poly (ADP-Ribose) Polymerase \\ Metabolism Group, Laboratory of Molecular Endocrinology, Centre Hospitalier de l'Université Laval Research Center and \\ Laval University, Sainte-Foy, Québec, Canada, G1V 4G2, and Departments of 3Pharmacology and Toxicology and \\ ${ }^{4}$ Psychiatry, School of Medicine, Indiana University, Indianapolis, Indiana 46202
}

Several members of the IL- $1 \beta$-converting enzyme (ICE) family of proteases recently have been implicated in the intracellular cascade mediating the apoptotic death of various cell types. It is unclear, however, whether ICE-related proteases are involved in apoptosis of mammalian neurons and, if so, how they are activated. Here we report the cloning of an ICE-related protease (IRP) from rat brain, which displays strong sequence identity to human CPP32. In situ hybridization histochemistry reveals that this IRP $\mathrm{mRNA}$ is expressed in neuron-enriched regions of the developing and adult rat brain but is profoundly downregulated in the adult (compared with developing) brain. To investigate whether this IRP is involved in the death of neurons in the developing brain, we studied IRP expression in cultured cerebellar granule neurons. In cultured cerebellar granule neurons, reduction of extracellular $\mathrm{K}^{+}$reliably induces apoptosis and stimulates overexpression of IRP mRNA. The latter is especially prominent $4 \mathrm{hr}$ after switching from high $\mathrm{K}^{+}$ to low $\mathrm{K}^{+}$medium. The expression of IRP mRNA was maintained at this level for at least $8 \mathrm{hr}$ and was followed by apoptotic death of these neurons. Induction of IRP mRNA and cell death are blocked completely by adding depolarizing concentrations of $\mathrm{K}^{+} \leq 90$ min after switching to low $\mathrm{K}^{+}$medium (i.e., before the commitment point for apoptosis) and partially blocked by brain-derived neurotrophic factor (BDNF), which also partially rescues granule neurons from low $\mathrm{K}^{+}$-induced apoptosis. In addition, overexpression of IRP cDNA in HeLa cells results in cell death accompanied by strong internucleosomal cleavage of DNA, a typical feature of apoptosis. Finally, we detected cleavage of the putative death substrate poly (ADP-ribose) polymerase (PARP), beginning $8 \mathrm{hr}$ after changing from high $\mathrm{K}^{+}$to low $\mathrm{K}^{+}$medium, coinciding with the time course of induced expression of the IRP gene. Our data suggest that transcriptional activation of IRP could be one of the mechanisms involved in the apoptotic death of cerebellar granule neurons.

Key words: ICE-related protease; CPP32/YAMA/apopain; neuronal apoptosis; molecular cloning; cerebellar granule neurons
The death of central neurons is widely recognized as a normal feature of vertebrate development. During cerebellar development, for example, granule neurons, which are among the most abundant neuronal phenotype, are generated postnatally in the external germinal layer where they differentiate, migrate to the granule layer, and finally are innervated by mossy fiber axons (Altman, 1972). More than 50\% of these neurons die before completion of their postnatal migration (Landis and Sidman, 1978). The precise nature of this fatal selection, however, remains a mystery. Previous studies suggest that the death of these neurons occurs via apoptosis, a physiological mechanism by which a cell dies via transcriptional and translational activation of an intrinsic cell death or suicide program (Raff et al., 1993; Wood et al., 1993). Several lines of evidence also suggest that apoptotic cell death not only is required for normal CNS development but is involved in pathological neuronal death, which occurs in neurodegenerative disorders such as Alzheimer's disease (Cotman and

Received Sept. 17, 1996; revised Dec. 2, 1996; accepted Dec. 11, 1996.

We thank Drs P. C. May and M. Glinn for helpful discussions and critical reading of this manuscript. GenBank accession number for IRP, U84410.

Correspondence should be addressed to Dr. Binhui Ni, Lilly Research Laboratories, Lilly Corporate Center, Indianapolis, IN 46285.

Copyright (C) 1997 Society for Neuroscience $0270-6474 / 97 / 171561-09 \$ 05.00 / 0$
Anderson, 1995; LaFerla et al., 1995; Lassmann et al., 1995), in which neuronal cell loss is a prominent feature.

Evidence that IL- $1 \beta$-converting enzyme (ICE), an ICE-like protease, or both are required for apoptosis derives from the fact that overexpression of ICE or its homologs in transfected cell lines results in cell death, which can be blocked by the crmA protein, an ICE inhibitor (Miura et al., 1993). Although several ICE-like proteases have been identified in cells from the immune system and various tumor cell lines, it is unknown whether any of these proteases are involved in neuronal apoptosis or how these proteases are activated in neurons. Of the nine ICE-related genes cloned to date, Nedd2 and ICE are the only two unequivocally shown to be expressed in the CNS. The Nedd2 gene is expressed in neurons and is regulated developmentally (Kumar et al., 1994). In contrast, low levels of ICE can be detected in non-neuronal cells of brain. There is also evidence that ICE itself may not be the trigger for mammalian neuronal apoptosis, because central neurons develop normally in ICE-deficient mice, despite major defects in ICE-dependent generation of mature IL- $1 \beta$ and other cytokines (Kuida et al., 1995; Li et al., 1995). These findings strongly suggest that there are other cysteine protease(s) involved in neuronal apoptosis.

Understanding the cellular events underlying neuronal apo- 
A

GAATTCGGCTTGGTAGCGACCGGCGCTCAGCTGGAATTCCGGGGAGCTTGGAACGGTACG CGAAGAAAAGTGACCATGGACAACAACGAAACCTCCGTGGATTCAAAATCCATTAATAAT

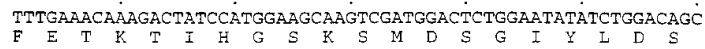
AGTTACAAAATGGATTACCCTGAAATGGGCTTGTGTATAATAATTAATAÁTAAGAACTTC
$\mathrm{S} Y \mathrm{Y} \mathrm{K}$ CATAAAAGCACTGGAATGTCAGCTCGCAATGGTACCGATGTCGATGCAGCTAACCTCAGA

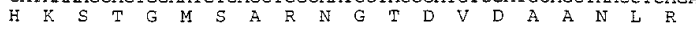

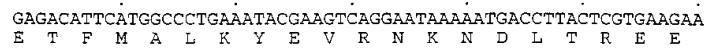

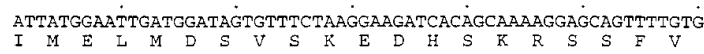
$\begin{array}{lllllllllllllllllll} & M & E & L & M & D & S & V & S & K & E & D & H & S & K & R & S & S & F\end{array}$ $C V$ I L S H G D E G V I F G T N G P V D

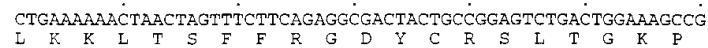
AAACTCTICATCATTCAGGCCTGCCGAGGTACAGAGCTGGACTGCGGTATTGAGACAGAC

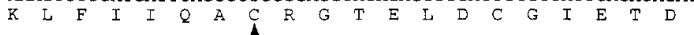

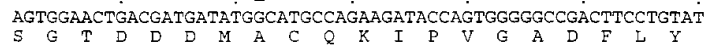
GCTTACTCTACCGCACCCGGTTACTATTCCTGGAGAAATTCAAGGGACGGGTCATGGTTC $\begin{array}{llllllllllllllllllllll}A & Y & S & I & A & P & G & Y & Y & S & W & R & N & S & R & D & G & S & W & F\end{array}$

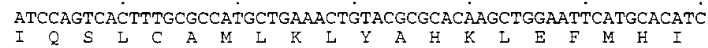

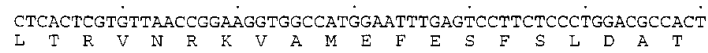
TTCCACGCAȦAGAAACAGATCCCGTGTATTETGTCAATGCTCACAAAAGÁACTGTACTTT $\begin{array}{llllllllllllllllllll}F & H & A & K & K & Q & I & P & C & I & V & S & M & L & T & K & E & L & Y & F\end{array}$ $\underset{\mathrm{Y}}{\mathrm{H} \text { TATCAAAAGGATGACTGGGAGTGGGGTAGGGGCATGTTTCTGTTTTGGTTTTTTTTT }}$ GGTTTTTGGTTTGTTTTTT'TTTTTTTATTTGAATGCCAAATGAGAAAACTGTCAGGGAG ACTTTTTTTITCCCCTCTCATTTAAATCAAATCCGATGTTCCAGGTCGTCATTGAACAAT ACCACTGCCTGCAATGCAGCCACAATACAATACCTCAGCTTTGATATCAGCCGGAaTTCC B GCCGATACTGACGGGCTCCAGGAGTCAAGCCGAATTC

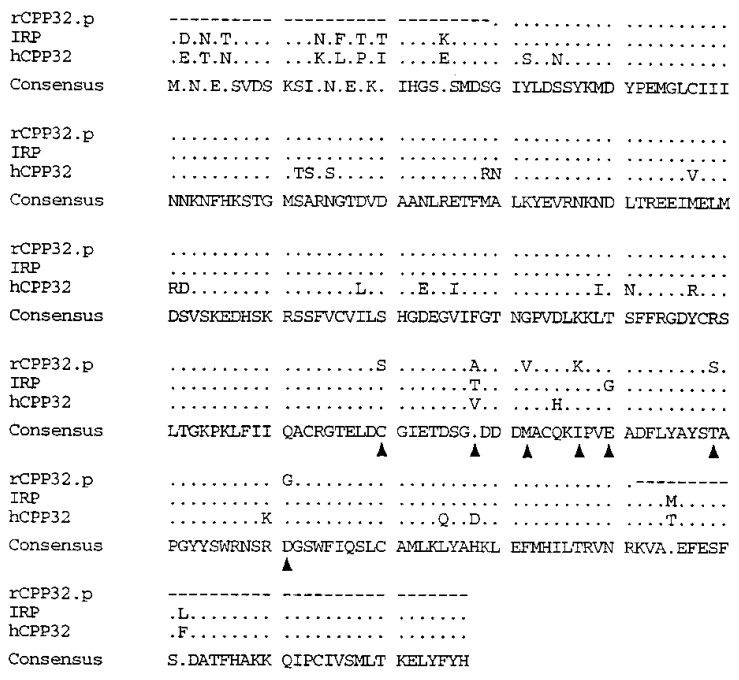

Figure 1. The nucleotide and deduced amino acid sequence of IRP-1. $A$, The deduced amino acid sequence of the encoded polypeptide is indicated in the single letter code below the nucleotide sequence. The putative active site cysteine is indicated by an arrowhead. B, Alignment of IRP with human CPP32 ( $h C P P 32)$ and a recently reported rat partial sequence of CPP32 (rCPP32.p). Mismatched amino acids and the consensus protein sequence are shown. IRP differs by seven amino acids (indicated by arrowheads) with the rat partial sequence of CPP32 reported recently by Flaws et al. (1995). Five of those are identical between IRP and human CPP32, which suggests that our IRP is closer to the human CPP32.

ptosis may prove useful for developing neuroprotective agents as well as therapeutic interventions for neurodegenerative disorders. We have characterized and used cultured cerebellar granule neurons as a model to identify the intrinsic mechanisms underlying
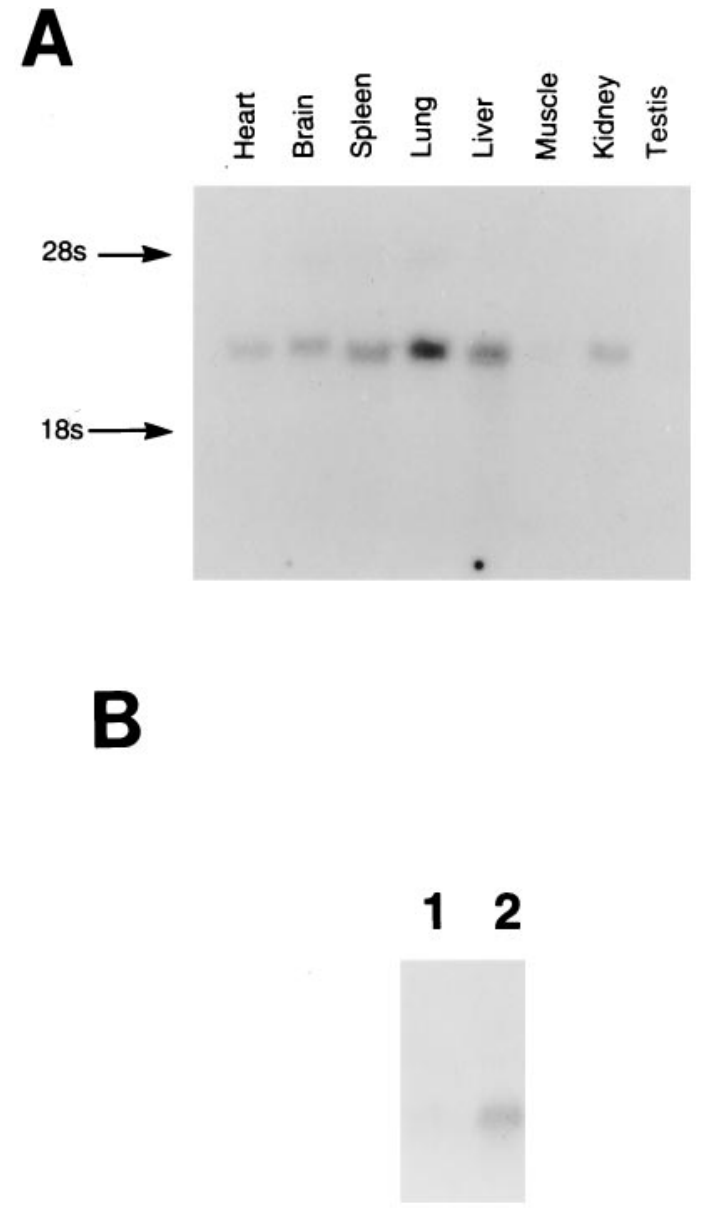

Figure 2. Tissue distribution of IRP mRNA. $A$, Northern analysis of IRP mRNA detected in multiple tissues of the rat $\left[2 \mu \mathrm{g}\right.$ of poly $\left(\mathrm{A}^{+}\right) \mathrm{RNA}$ from each tissue per lane] by using the rat IRP cDNA (see text for details). IRP mRNA is expressed in most tissues and at low levels in muscle and testis. $B$, IRP transcripts are expressed in RNA extracted from hippocampus (lane 1) and cerebellum (lane 2) (20 $\mu \mathrm{g}$ of total RNA from each brain region per lane). The blots were hybridized with the IRP cDNA probe, as described in the text, and exposed to Kodak X-Omat film with doubleintensifying screens for $2 \mathrm{~d}$ at $-80^{\circ} \mathrm{C}$.

neuronal apoptosis. Postmitotic granule neurons readily can be maintained in vitro in their fully differentiated state for several weeks if depolarized with high concentrations of $\mathrm{K}^{+}$. We (Yan et al., 1994) and others (D'Mello et al., 1993) have shown previously that exposing cultured cerebellar granule neurons to nondepolarizing culture conditions (by lowering extracellular $\left[\mathrm{K}^{+}\right]$) results in cell death accompanied by all the morphological and biochemical characteristics of apoptosis, including cytoplasmic blebbing, condensation/aggregation of nuclear chromatin, and internucleosomal DNA fragmentation. Cultured cerebellar granule neurons, therefore, represent a good model system for studying the cellular/molecular mechanisms underlying neuronal apoptosis.

During the course of our studies, we have attempted to identify ICE-related proteases that may affect apoptosis in neurons. Here we report the cloning of an ICE-related protease, designated IRP, from the rat brain. Given the sequence homology between this IRP and the previously characterized human cysteine protease (P32), CPP32, our cDNA may represent the rat homolog of CPP32. In situ hybridization histochemistry reveals that the IRP mRNA is expressed at relatively high levels in neuron-enriched 
A

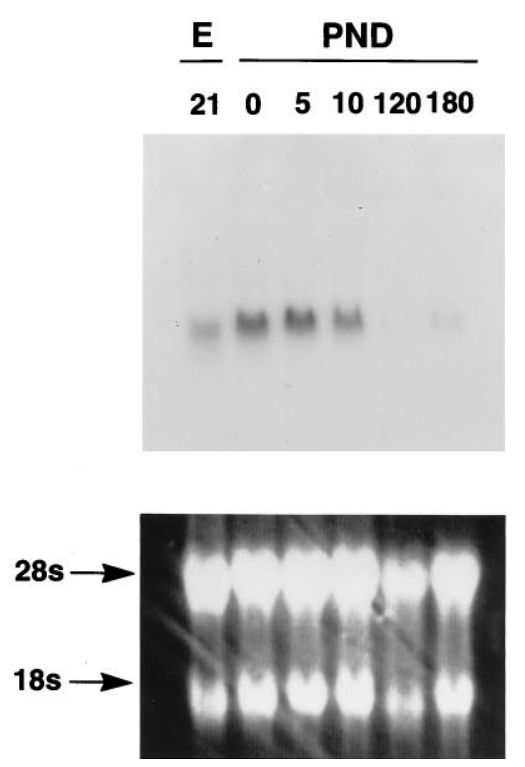

B

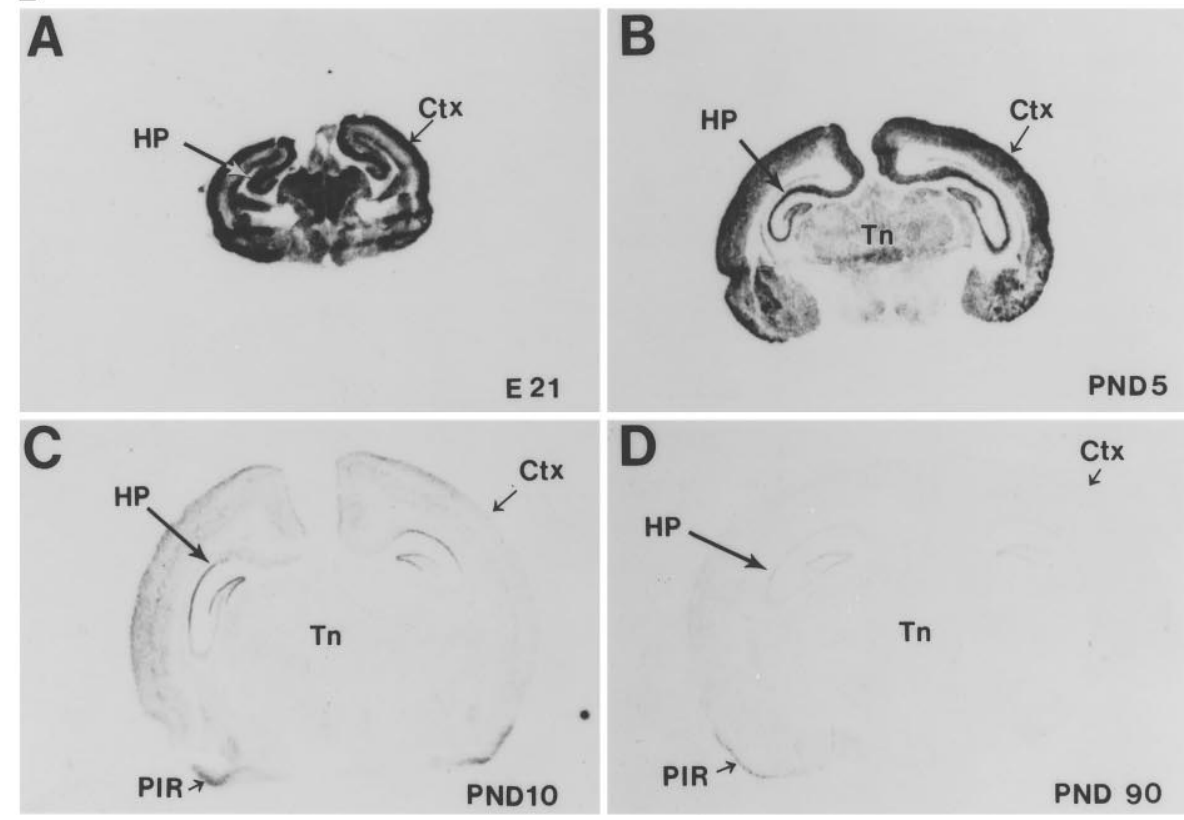

Figure 3. Expression of IRP mRNA during development of the rat brain. $A$, Developmental expression of IRP mRNA in the rat brain revealed by Northern blot analysis. Total RNA ( $20 \mu \mathrm{g}$ of RNA per lane) was isolated from whole rat brain at various developmental stages and hybridized with IRP cDNA. The Northern analysis showed that IRP is highly expressed in embryonic and early postnatal brain development. Bottom panel, Total RNA in the agarose gel was stained with ethidium bromide before being transferred to nitrocellulose membrane for hybridization. $B$, Coronal cryostat-prepared tissue sections of the developing rat brain were probed with a labeled antisense cRNA probe and processed for in situ hybridization as described in Materials and Methods. The hybridization signal was visualized by bright-field microscopy. Hybridization with the IRP probe resulted in a strong hybridization signal in neuron-enriched regions such as cortical plate $(C t x)$ and hippocampal formation $(H P)$ and in midline structures such as various thalamic and hypothalamic nuclei $(T n)$ in embryonic day $(E)$ and up to postnatal day 5 (PND 5). A weak hybridization signal was observed in the same regions of the adult rat brain, whereas a somewhat stronger hybridization signal was detected in the piriform cortex (PIR).

regions of the developing rat brain but is absent, or expressed only at low levels, in these same regions of the adult rat brain. Finally, a marked increase in IRP mRNA, presumably caused by IRP gene transcription, occurs just before apoptosis of cultured cerebellar granule neurons. Taken together, our data suggest that this IRP, closely related if not identical to CPP32, that is expressed predominantly in the developing rat brain may be involved in the apoptotic death of certain populations of neurons known to occur during development.

\section{MATERIALS AND METHODS}

Library screening and cloning of the ICE-like protease. A rat brain cDNA library was obtained from Stratagene (La Jolla, CA). Approximately $5 \times$ $10^{5}$ plaques were screened with filter hybridization. For screening, 21 mer oligonucleotides derived from the consensus sequence (IIQACRG) of ICE-like proteases were radioactively labeled with $\left[{ }^{32} \mathrm{P}\right]-\mathrm{r}-\mathrm{ATP}$, and hybridization was performed overnight at $42^{\circ} \mathrm{C}$ in $50 \%$ formamide, $5 \times$ SSPE, $5 \times$ Denhardt solution, $0.1 \%$ SDS, and $100 \mu \mathrm{g} / \mathrm{ml}$ denatured salmon sperm DNA. Filters were washed in $2 \times$ SSC and $0.5 \%$ SDS at room temperature for $30 \mathrm{~min}$, followed by an additional wash in $2 \times \mathrm{SSC}$ and $0.1 \% \mathrm{SDS}$ at $55^{\circ} \mathrm{C}$ for $30 \mathrm{~min}$. Of the five phage plaques that screened positive, two were confirmed further by rehybridization of their excised plasmids with the labeled IRP probe. One of the clones, designated IRP-1, was sequenced in both directions and analyzed with GCG programs (University of Wisconsin) as described (Ni et al., 1994). GENE WORK was used for sequence comparisons.

DNA sequencing and sequence analysis. The nucleotide sequence of the IRP cDNA clone was determined for both strands. Sequence reactions were performed with double-stranded DNA templates, sequence-specific oligonucleotide primers, fluorescently labeled dideoxynucleotide terminators (Applied Biosystems, Foster City, CA), and Ampli-Taq polymerase in cycle-sequencing reactions modified as described (Ni et al., 1994). Individual sequences were assembled with an Applied Biosystems model 670 Inherit sequence analysis system and edited with EDITVIEW soft- ware. Sequences were manipulated and analyzed with programs from the Genetics Computer Group. Sequences were compared with sequence data bases by using the BLAST server network at the National Center for Biotechnology Information (Bethesda, MD).

$D N A$ transfection and soluble DNA isolation. HeLa cells were maintained routinely at $37^{\circ} \mathrm{C}$ in DMEM with $10 \%$ fetal bovine serum (FBS), $100 \mathrm{U} / \mathrm{ml}$ of penicillin, and $100 \mu \mathrm{g} / \mathrm{ml}$ of streptomycin under $5 \% \mathrm{CO}_{2} /$ $95 \%$ air. DNA transfection was performed with the Lipofectamine method as described by the manufacturer (BRL, Bethesda, MD). Briefly, before transfection, the culture medium was changed to OPTI-MEM. Lipofectamine and $16 \mu \mathrm{g}$ of pure DNA (pcDNA3-IRP-1 or vector only) were added to $5 \times 10^{5}-10^{6}$ cells cultured in a $10 \mathrm{~cm}$ dish in $8 \mathrm{ml}$ of OPTI-MEM medium. The cells were cultured at $37^{\circ} \mathrm{C}$ for $5 \mathrm{hr}$, followed by addition of $10 \%$ FBS to stop the transfection. The transfected cells were cultured for $48 \mathrm{hr}$ before DNA was harvested for fragmentation analysis. The dead cells induced by IRP were estimated by measuring viable cells after transfection with IRP, as compared with cultures transfected with control vector alone. The cells were harvested and washed with PBS. Cell pellets were lysed with $100 \mu \mathrm{l}$ of lysis buffer (1\% NP-40, 20 $\mathrm{mm}$ EDTA, and $50 \mathrm{~mm}$ Tris- $\mathrm{HCl}, \mathrm{pH} 7.5)$ and centrifuged for $5 \mathrm{~min}$ at $5000 \times g$. The supernatants were collected, and the pellets were extracted with the same amount of lysis buffer. The supernatants were treated with RNase A (final concentration $5 \mu \mathrm{g} / \mu \mathrm{l}$ ) for $2 \mathrm{hr}$ at $37^{\circ} \mathrm{C}$ and then with protease $\mathrm{K}$ (final concentration $2.5 \mu \mathrm{g} / \mu \mathrm{l}$ ) overnight at $56^{\circ} \mathrm{C}$. The DNA was precipitated after addition of $1: 10(\mathrm{v} / \mathrm{v})$ of $3 \mathrm{M}$ potassium acetate and 1 vol of isopropyl alcohol for $1 \mathrm{hr}$ at $4^{\circ} \mathrm{C}$. The DNA was dissolved in loading buffer and separated on a $1.5 \%$ agarose gel.

Preparation of cultured cerebellar granule neurons. Cerebellar granule neurons were prepared from 8-d-old Sprague Dawley rat pups (15-19 gm), as previously described (Marini and Paul, 1992). Briefly, cells were dissociated from freshly dissected cerebella by mechanical disruption in the presence of trypsin and DNase and then plated in poly-L-lysinecoated $35 \mathrm{~mm}$ culture plates. Cells were seeded at a density of 1.5-1.8 $\times$ $10^{6}$ cells $/ \mathrm{ml}(2 \mathrm{ml} / \mathrm{dish})$ in basal-modified Eagle's medium containing $10 \%$ FBS and $25 \mathrm{~mm} \mathrm{KCl}$. Cytosine arabinoside $(10 \mu \mathrm{M})$ (Ara-C) was added to the culture medium after $24 \mathrm{hr}$ to arrest the growth of non-neuronal cells. 


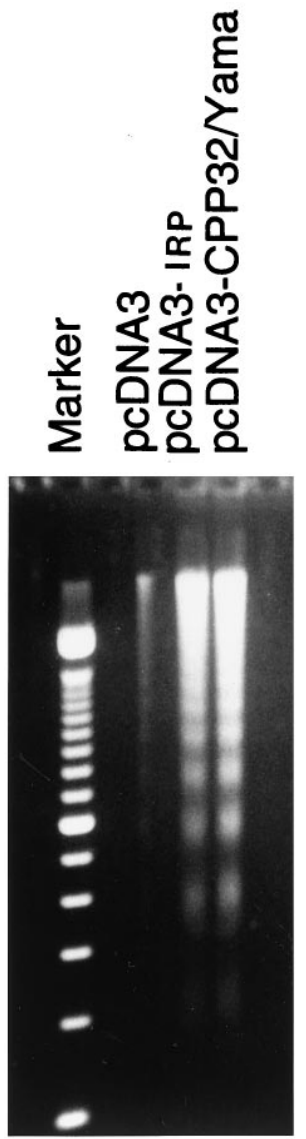

Figure 4. Overexpression of IRP cDNA initiates apoptosis in HeLa cells. IRP and human CPP32/YAMA/apopain cDNAs, respectively, were subcloned into the mammalian expression vector pcDNA3 containing the human cytomegalovirus promoter. DNA transfection of HeLa cells was performed with the Lipofectamine method, as described in Materials and Methods. Soluble DNA isolated from HeLa cells transiently transfected with pcDNA3-IRP and pcDNA3-CPP32 revealed strong nucleosomal repeats, a typical feature of apoptosis. No DNA fragmentation was observed in vector-transfected cells.

D-Glucose $\left(100 \mu \mathrm{l}\right.$ of a $100 \mathrm{~mm}$ solution prepared in sterile $\left.\mathrm{H}_{2} 0\right)$ was added to the cultures on day 7 and every fourth day thereafter.

Assessment of neuronal viability and detection of DNA fragmentation. Viable granule neurons were quantified after staining with fluorescein formed from fluorescein diacetate, which is deesterified only by living cells (Marini and Paul, 1992; Yan et al., 1994). Briefly, after incubation with fluorescein diacetate $(10 \mu \mathrm{g} / \mathrm{ml}$; Sigma), neurons were examined and photographed under UV light microscopy, and the number of neurons per representative low-power field was counted from the photomicrographs. Values are generally expressed as a percentage of control cultures in each experiment.

Northern and Western blot analyses. Northern blots of rat brain RNA were obtained from Clontech (Palo Alto, CA). Blots were prehybridized at $42^{\circ} \mathrm{C}$ for $2 \mathrm{hr}$ in buffer containing $50 \%$ formamide, $5 \times$ SSPE, $10 \times$ Denhardt's, 2\% SDS, and $100 \mu \mathrm{g} / \mathrm{ml}$ salmon sperm DNA. Hybridization was performed overnight in the same buffer containing denatured $\left[{ }^{32} \mathrm{P}\right]$ labeled cDNAs from the IRP clone as described. Blots were washed at $50^{\circ} \mathrm{C}$ in $2 \times$ SSC and $0.1 \%$ SDS and exposed to Kodak X-OMAT film at $-70^{\circ} \mathrm{C}$ with a Cronex lightening plus intensifying screen.

For Western blotting, protein samples from each time point were separated by electrophoresis and then transferred to Hybond-ECL. Western blotting was performed with the ECL method, as described by the manufacturer (Amersham, Arlington Heights, IL). Briefly, blots were incubated in PBS plus $0.1 \%$ Tween-20 (PBS-T) containing 5\% milk powder for $1 \mathrm{hr}$, followed by several washes with PBS-T in room temperature, and then incubated with primary antibody c-2-10 diluted 1:10,000 for 2-3 hr. After being washed with PBS-T, membranes were
A
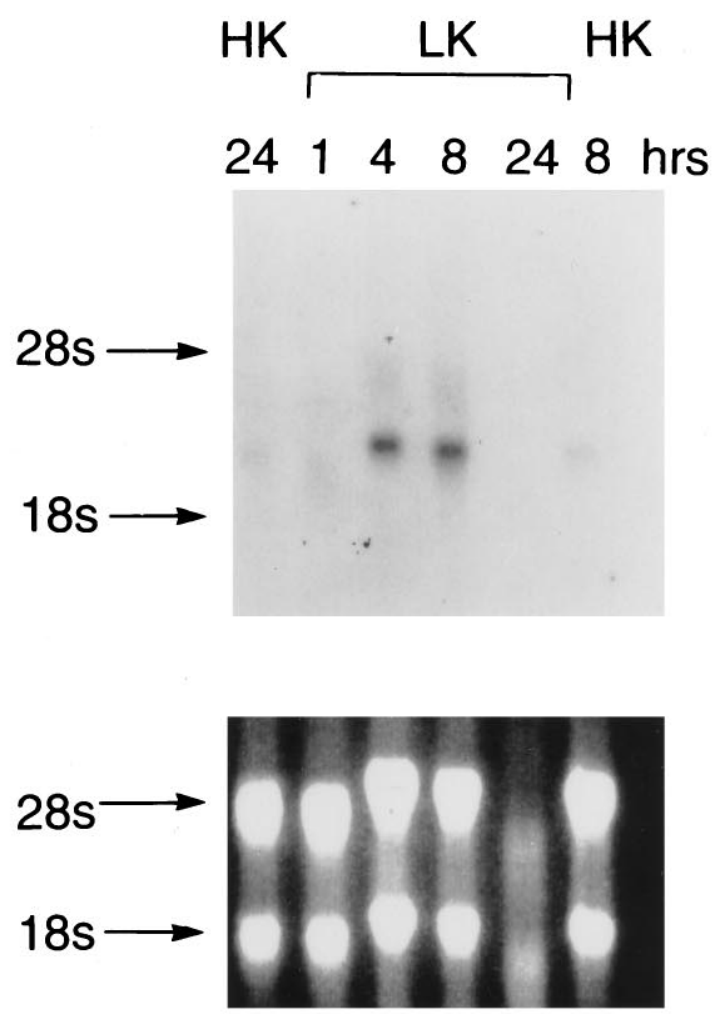

B

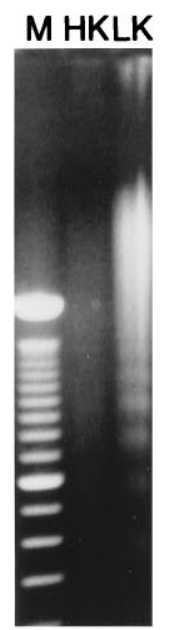

Figure 5. Reduction of extracellular $\mathrm{K}^{+}$induces overexpression of IRP mRNA and internucleosomal DNA fragmentation of granule neurons. $A$, Each lane contains $20 \mu \mathrm{g}$ of total RNA extracted from cultured cerebellar granule neurons at the indicated time points. The blots were hybridized with an IRP cDNA probe, as described in the text, and exposed to Kodak $\mathrm{X}$-Omat film with double-intensifying screens at $-80^{\circ} \mathrm{C}$ for $2 \mathrm{~d}$. IRP transcripts were induced dramatically in cultured granule neurons 4 and 8 hr after switching from $H K$ to $L K$ medium. The low amount of RNA loaded on the gel from $24 \mathrm{hr} L K$ cultures resulted from cell death of granule neurons ( $\geq 80 \%) 24 \mathrm{hr}$ after switching to LK medium. Bottom panel, Total RNA in the agarose gel was stained with ethidium bromide before being transferred to nitrocellulose membranes for hybridization. $B$, DNA fragmentation characteristic of apoptotic death was induced in cerebellar granular neurons by switching to $L K$ medium. Soluble DNA was isolated from both $H K$ (lane 2) and LK (lane 3) cells $24 \mathrm{hr}$ after switching the medium. Lane 1 was loaded with marker $(M)$. 
A

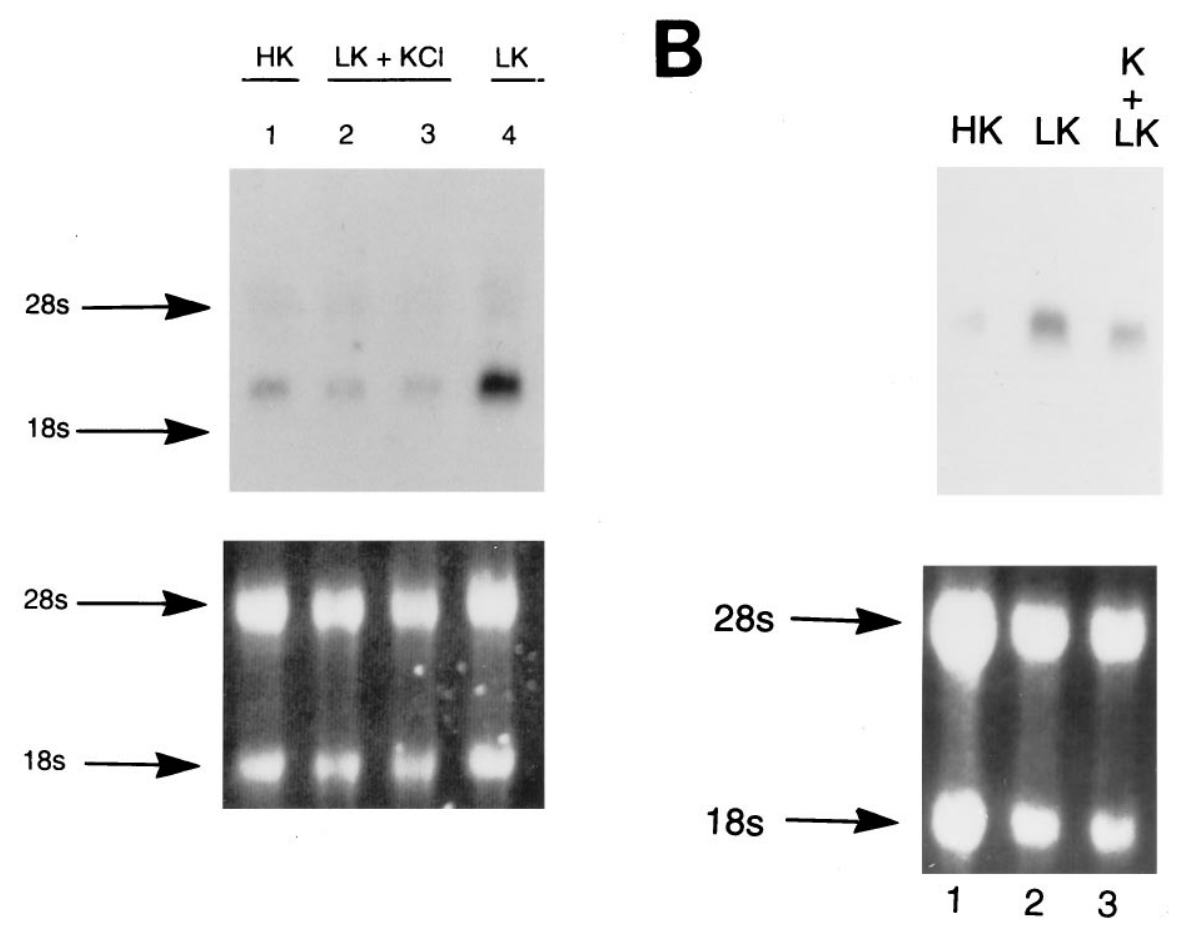

Figure 6. Induction of IRP mRNA is blocked by replenishment with $\mathrm{HK}$. Northern analysis was performed as described in the legend to Figure 5. A, Total RNA $(20 \mu \mathrm{g})$ was isolated from each condition $8 \mathrm{hr}$ after switching to $L K$ medium. IRP mRNA was induced in granule neurons $8 \mathrm{hr}$ after changing medium from $H K$ to $L K$ (compare lanes 1 and 4), consistent with time course of IRP mRNA induction (see Fig. 5A). However, the induction of IRP mRNA was blocked completely by raising the $\left[\mathrm{K}^{+}\right]_{\mathrm{e}}$ to $25 \mathrm{~mm} \mathrm{KCl} 30 \mathrm{~min}$ (lane 2) and 90 min (lane 3) after switching from $H K$ to $L K$ medium. $B$, Induction of IRP mRNA and apoptosis of cerebellar granule neurons induced by LK medium (data not shown) could be prevented only partially by the addition of depolarizing $\left[\mathrm{K}^{+}\right]_{\mathrm{e}}(20 \mathrm{mM} \mathrm{KCl})$ $5 \mathrm{hr}$ after being switched to the $L K$ medium (lane 3). Bottom panel, Total RNA in the agarose gel was stained with ethidium bromide before being transferred to nitrocellulose membranes for hybridization.

incubated with HRP-labeled antibody (1:2000) for $1 \mathrm{hr}$ at room temperature. The blots subsequently were washed several times in PBS-T to remove secondary antibody. Finally, the membranes were developed by the ECL detection system and exposed to Hyperfilm-ECL (Amersham).

In situ hybridization histochemistry. In situ hybridization analysis was performed as described in detail elsewhere (Ni et al., 1996). Briefly, frozen sections $(15 \mu \mathrm{m})$ were prepared on a cryostat, mounted on poly-L-lysine-coated glass slides, and dried at room temperature. Before hybridization, sections were warmed to $25^{\circ} \mathrm{C}$, fixed in $4 \%$ formaldehyde, and immersed for $10 \mathrm{~min}$ in $0.25 \%$ acetic anhydride $/ 0.1 \mathrm{M}$ triethanolamine hydrochloride/ $0.9 \% \mathrm{NaCl}$. The ${ }^{35} \mathrm{~S}$-labeled riboprobes were added to a hybridization buffer composed of $50 \%$ formamide, $0.3 \mathrm{M} \mathrm{NaCl}, 20$ mm Tris-HCl, $\mathrm{pH} 8,5 \mathrm{~mm}$ EDTA, $500 \mu \mathrm{g}$ of tRNA/ml, $10 \%$ dextran sulfate, $10 \mathrm{~mm}$ dithiothreitol, and $0.02 \%$ each of bovine serum albumin, Ficoll, and polyvinylpyrrolidone. Then the slides were incubated in a humidified chamber overnight at $55^{\circ} \mathrm{C}$. The sections were treated with RNase A $(20 \mu \mathrm{g} / \mathrm{ml})$ for $30 \mathrm{~min}$ at room temperature, followed by a 15 min wash in $0.1 \times \mathrm{SSC}$ at $55^{\circ} \mathrm{C}$. For analysis at the cellular level, the slides were dipped in Kodak NTB3 nuclear emulsion, stored with desiccant at $4^{\circ} \mathrm{C}$ for $10 \mathrm{~d}$, developed, and counterstained with hematoxylin/eosin phloxine for microscopic evaluation.

\section{RESULTS}

\section{Cloning of an ICE-related protease from rat brain}

To clone ICE-related protease(s) present in the CNS, we screened, under low stringency conditions, a rat brain cDNA library using oligonucleotides derived from consensus sequences of several members of the ICE family, including ICE, CED-3, and CPP32/YAMA/ apopain. Five positive clones that strongly hybridized to the $\left[{ }^{32} \mathrm{P}\right]-$ labeled probe were isolated. Restriction endonuclease analysis and/or sequencing of these clones revealed two different sequences that showed some similarity at the amino acid level to ICE-like proteases (see below). These two cDNAs are referred to as IRP-1 and IRP-2, respectively. Sequence analysis of IRP-1 predicted an open reading frame of 831 bases, corresponding to a protein of 277 amino acids with an apparent molecular mass of 31,449 Da (32 kDa) (Fig. 1A). The ATG initiation codon at position 1, which is preceded by an upstream in-frame stop codon, matches the Kozak consensus initiation sequence (CCATGG) for the initiation of translation (Kozak, 1984). A computer analysis revealed that the protein en- coded by IRP-1(now designated IRP) shares strong sequence similarity at the amino acid level with ICE-related proteases and especially human CPP32/YAMA/apopain, which recently has been cloned from tumor cell lines (Fernandes-Alnemri et al., 1995; Nicholson et al., 1995; Tewari et al., 1995) (Fig. 1B). In fact, IRP-1 is $\sim 85$ and $96 \%$ identical at the amino acid level to the human and a recently reported rat partial sequence of CPP32 (Flaws et al., 1995), respectively. However, of the 212 amino acids (deduced from the partial nucleotide sequence of this rat CPP32 cDNA), IRP-1 differs by seven amino acids (Fig. $1 B$ ). When compared with the human CPP32, IRP-1 is more homologous to human CPP32 than is the recently reported partial rat $\mathrm{CPP} 32$, which strongly suggests that IRP-1 represents a rat homolog of human CPP32. Partial sequence of IRP-2 reveals some homology to IRP-1 and other ICE-related protease(s). This clone awaits further characterization.

We initially examined expression of the IRP gene in multiple tissues of the rat by probing poly $\left(\mathrm{A}^{+}\right)$RNA from heart, brain, lung, liver, skeletal muscle, kidney, and testis (Fig. $2 A$ ). The IRP probe detected a single mRNA species of $2.8 \mathrm{~kb}$ in size in heart, brain, lung, liver, and muscle, but not in kidney or testis. Northern analysis of RNA prepared from various regions of the adult rat brain showed that IRP is expressed primarily in the cerebellum and hippocampus (Fig. 2B).

\section{Expression of IRP mRNA during the fetal and postnatal development of rat brain}

Because the expression of IRP mRNA was relatively low in the adult rat brain, we examined IRP mRNA in the developing (fetal and neonatal) rat brain. As shown in Figure $3 A$, Northern analysis of mRNA derived from developing rat brain [embryonic day (ED) 18 to postnatal day (PND) 180] shows that IRP mRNA is considerably more abundant in embryonic and early postnatal brain. These experiments confirm that only low levels of IRP mRNA are expressed in the adult rat brain. The expression of IRP mRNA in embryonic brain is at least 20 times greater than that in the adult brain (data not shown). 


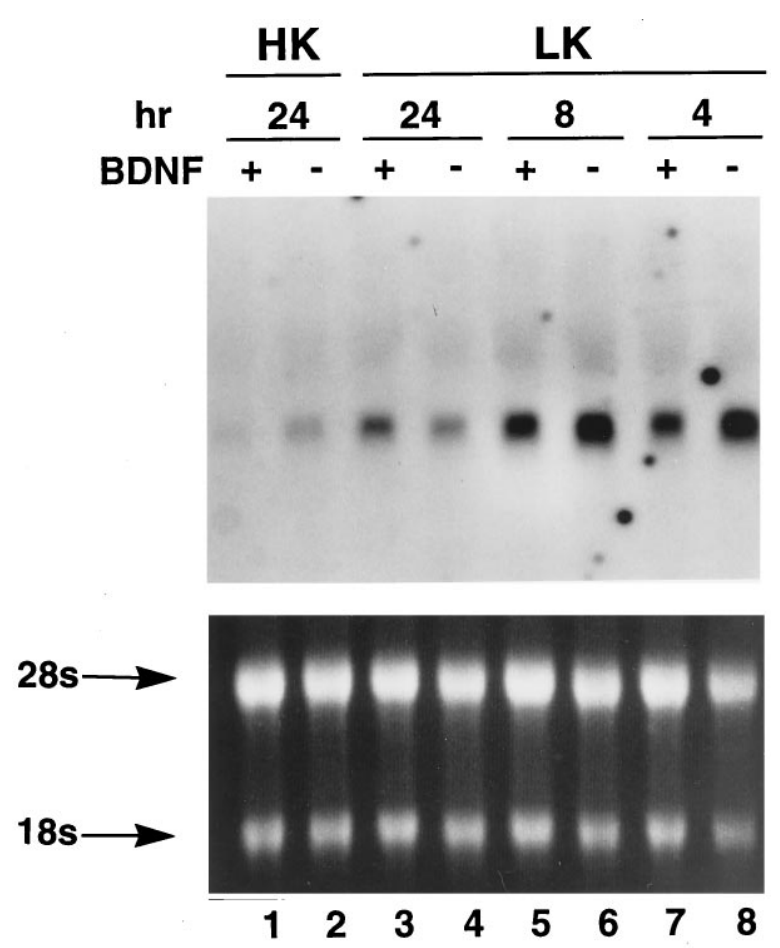

Figure 7. BDNF suppresses the overexpression of IRP and attenuates apoptosis of cultured cerebellar granule neurons. Northern analysis was performed as described in the legend to Figure 5. Total RNA $(20 \mu \mathrm{g})$ was isolated from each condition with or without $B D N F(50 \mathrm{ng} / \mathrm{ml}) 4 \mathrm{hr}$ after switching to $L K$ medium. Our Northern analysis showed that the IRP mRNA was induced in granule neurons 4 and $8 \mathrm{hr}$ after changing medium from $H K$ to $L K$ and that $B D N F$, a member of the neurotrophin family, could partially suppress the expression of IRP and rescue $\sim 30 \%$ granule neurons from apoptotic cell death (data not shown).

The developmental expression of IRP mRNA in brain was further studied using in situ hybridization, as illustrated in Figure $3 B$. Both pre- and postnatal stages were examined in this study and included ED 21 and PND 5, 10, and 90. IRP mRNA is expressed rather ubiquitously during early brain development (from ED 21 to PND 5) with higher levels of expression in neuron-enriched regions such as cortical plate (CP) and hippocampal formation (HP) and in midline structures such as various thalamic and hypothalamic nuclei (Tn). By contrast, only low levels of IRP mRNA are found in pyramidal neurons of the hippocampus, neurons of the cerebral cortex, and granule layer of the cerebellum after PND 10.

\section{Overexpression of IRP initiates apoptosis}

To determine whether an increase in IRP mRNA can induce apoptosis, we constructed an expression vector (pcDNA3) containing the IRP (pcDNA3-IRP) and hCPP32/YAMA/apopain (pcDNA-CPP32) cDNAs and then transiently transfected these cDNAs into HeLa cells for DNA fragmentation analysis. The percentage of survival of transfected cells was $\sim 39 \%$ of control (vector-transfected) cells after $24 \mathrm{hr}$ of culture. As shown in Figure 4, soluble DNA isolated from transiently transfected pcDNA-IRP and pcDNA3-CPP32 revealed 180 bp internucleosomal repeats, a typical feature of apoptosis. No internucleosomal DNA fragmentation was observed in vector-transfected cells. These data demonstrate that overexpression of IRP mRNA induces cell death and a DNA fragmentation pattern characteristic of apoptosis.

\section{Reduction of extracellular $\mathrm{K}^{+}$stimulates apoptosis and overexpression of IRP in cultured cerebellar granule neurons}

Postmitotic cerebellar granule neurons are maintained readily in vitro in their fully differentiated state for several weeks under depolarizing conditions $\left(\mathrm{HK}, 25 \mathrm{mM} \mathrm{K}^{+}\right)$. When the medium is changed to nondepolarizing conditions (LK, $5 \mathrm{~mm} \mathrm{~K}{ }^{+}$), the neurons subsequently die ( $\geq 50 \%$ neurons at $24 \mathrm{hr}$ ) and display morphological features of apoptosis, including cytoplasmic blebbing and heterochromatic clumping (Yan et al., 1994). To investigate whether an ICE-related protease is involved in granule neuron apoptosis, we probed RNA from neurons switched from HK to LK with the labeled IRP cDNA. As shown in Figure $5 A$, IRP mRNA is induced $4 \mathrm{hr}$ after switching from $\mathrm{HK}$ to $\mathrm{LK}$ medium, and a high level of expression is maintained for at least $8 \mathrm{hr}$ before cell death and internucleosomal DNA fragmentation. As previously reported, soluble DNA isolated from granule neurons switched to LK medium shows characteristic internucleosomal fragmentation (Fig. 5B).

\section{Expression of IRP $m R N A$ occurs after the commitment point for apoptosis in cultured cerebellar granule neurons}

The induction of apoptosis caused by changing cultured cerebellar granule neurons from HK to LK medium is blocked by the addition of both cycloheximide and actinomycin D (Yan et al., 1994). Moreover, both induction of IRP mRNA and apoptosis of cerebellar granule neurons induced by LK medium can be prevented completely by raising $\left[\mathrm{K}^{+}\right]_{\mathrm{e}}$ to $20 \mathrm{~mm} \mathrm{KCl} \leq 90 \mathrm{~min}$ after exposure to nondepolarizing conditions (Fig. 6A) and can be prevented only partially by the addition of depolarizing $\left[\mathrm{K}^{+}\right]_{\mathrm{e}}(20$ $\mathrm{mM} \mathrm{KCl}$ ) $\geq 4 \mathrm{hr}$ after being switched to the LK medium (Fig. 6B). The latter corresponds to a time point near the commitment point for LK-induced apoptosis (Galli et al., 1995; G. Yan, personal communication) and the point when overexpression of the IRP gene has been induced (Fig. 5A). These findings suggest that suppression of IRP gene expression by raising $\left[\mathrm{K}^{+}\right] \mathrm{e}$ is associated with cell viability.

\section{Brain-derived neurotrophic factor (BDNF) suppresses the overexpression of IRP and rescues neurons from \\ LK-induced apoptosis}

To further confirm that overexpression of IRP is associated with apoptotic cell death of cultured cerebellar granule neurons, we used a different protective paradigm with brain-derived neurotrophic factor (BDNF). BDNF previously has been shown to have a direct effect on mature cerebellar granule neurons (e.g., stimulation of c-fos expression) and can rescue $\sim 30-50 \%$ of cultured cerebellar granule neurons from low $\mathrm{K}^{+}$-mediated apoptosis (Kubo et al., 1995). Northern analysis revealed that treatment of cultured cerebellar granule neurons with BDNF (50 ng/ml) suppresses the expression of IRP induced by nondepolarizing incubation (LK) conditions (Fig. 7) and rescues $\sim 30 \%$ of neurons from apoptotic death (data not shown). Because BDNF enhances the survival of neurons by activation of a tyrosine kinase receptor gp145 trkB and not by depolarization (Klein et al., 1991), it is likely that suppression of IRP gene expression is associated with cell viability and not with depolarization itself.

\section{Cleavage of poly (ADP-ribose) polymerase (PARP) is associated with apoptosis of cerebellar granule neurons}

To examine whether upregulation of IRP mRNA subsequently leads to an increase in protease activity, we used a monoclonal 
A

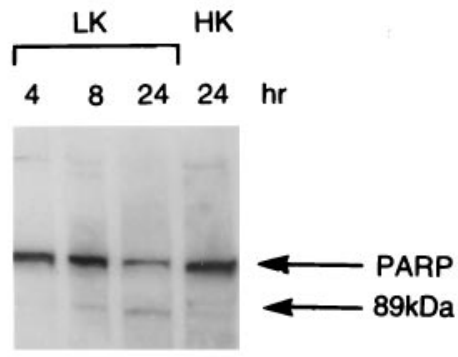

B

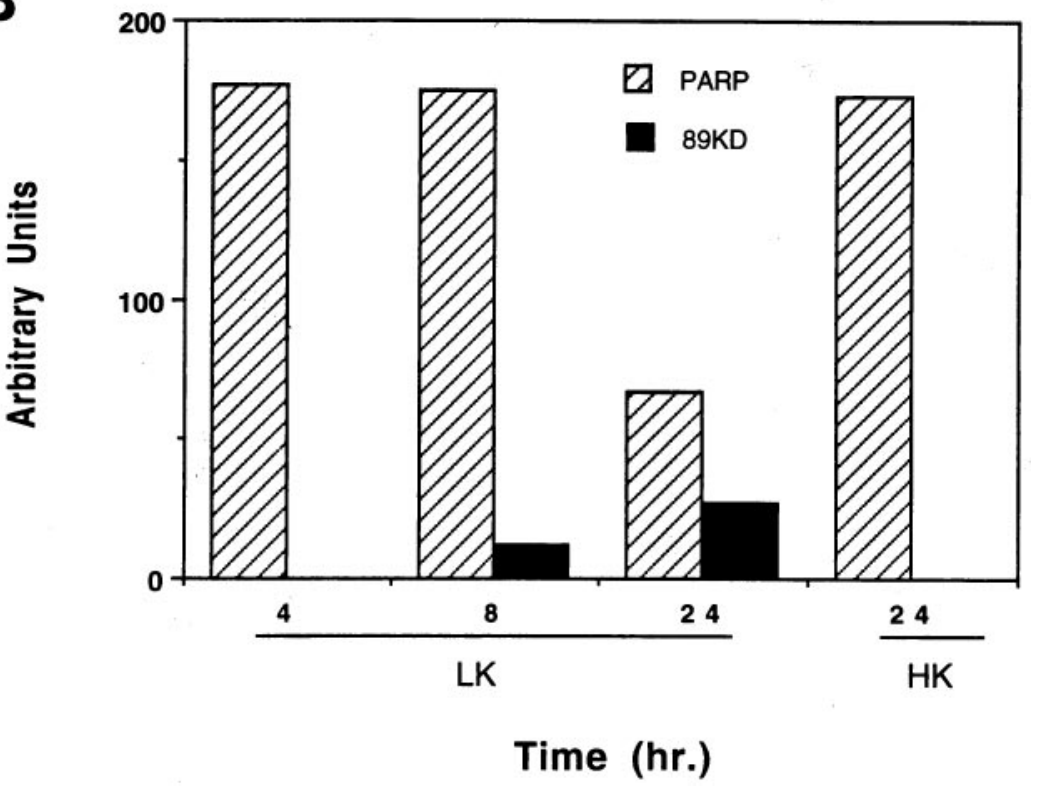

Figure 8. Cleavage of PARP by reduction of extracellular $\mathrm{K}^{+}$in cultured cerebellar granule neurons. $A$, Cultured granule neurons were lysed with lysis buffer from each time point after switching from $H K$ to $L K$ medium. Total proteins were separated by SDS-PAGE. Each lane contains $\sim 30 \mu \mathrm{g}$ of protein from the indicated time points. Immunoblots were incubated with monoclonal antibody C-2-10 and visualized with ECL, as described in Materials and Methods. PARP was cleaved to the $89 \mathrm{kDa}$ fragment 8 and $24 \mathrm{hr}$ after switching from HK to LK medium. B, Densitometric analysis of PARP cleavage measured by Western analysis was performed with NIH Image (National Institutes of Health, Bethesda, MD). antibody (2-c-10) against poly (ADP-ribose) polymerase (PARP) to examine the cleavage of this death substrate, which is specific for the CPP32 protease (Lazebnik et al., 1994; Tewari et al., 1995). As shown in Figure 8, a cleavage product ( $89 \mathrm{kDa}$ fragment) of PARP is clearly present at 8 and $24 \mathrm{hr}$ after changing from HK to LK medium and is associated with a corresponding decrease in the amount of full-length precursor (PARP). The PARP cleavage that occurs after HK to LK medium switch displays a time course in good agreement with the time course of induction of the IRP transcript and manifestation of apoptotic cell death.

\section{DISCUSSION}

Apoptosis is an important mechanism underlying the death of neurons, which occurs during the normal development of the nervous system. Although several ICE-like proteases have been identified or implicated as cell death genes in the invertebrate nervous system, it is not yet clear whether ICE-like proteases are involved in apoptosis of mammalian neurons. The studies de- scribed herein were initiated to identify ICE-like protease(s) that are responsible for apoptosis in mammalian neurons. We have isolated and identified a cysteine protease of the CED-3/ICE family, designated IRP. Unlike ICE, however, IRP mRNA is expressed in the brain and is enriched in neurons, including pyramidal neurons and granule neurons of the hippocampus, cerebral cortex, and cerebellum.

The highest sequence homology among ICE-like proteases lies near their active site containing a Cys residue required for proteolytic activity. This site was, therefore, used as a consensus sequence for generating the degenerate oligonucleotide probes for screening a rat brain cDNA library that led to the cloning of IRP. This IRP shares a highly conserved active site common to all ICE-like proteases and, not surprisingly, shows a high degree of identity (85\% at the amino acid level) to CPP32/YAMA/apopain (Fernandes-Alnemri et al., 1995; Tewari et al., 1995). Given that the degree of homology between the rat IRP reported here and CPP32/Yama/apopain is $\sim 85 \%$, we provisionally conclude that our rat IRP is the rat homolog of CPP32/YAMA/apopain. How- 
ever, a partial sequence (derived from a PCR product) of a rat CPP32 recently has been reported (Flaws et al., 1995), and we note differences in the deduced amino acid sequence of at least seven amino acids. Conceivably, therefore, our cloned rat IRP may represent a closely related protease, i.e., similar to but not identical to rat CPP32. Further characterization of this and other rat IRPs (including IRP-2) will be required, however, to clarify the uniqueness of this IRP compared with CPP32/Yama/apopain. Nonetheless, until other IRPs from rat brain are characterized more fully, we conclude that IRP-1 is a rat homolog of human CPP32.

Using both Northern analyses and in situ hybridization histochemistry, we have characterized the developmental expression of IRP in the rat brain. Interestingly, relatively high expression of IRP mRNA was observed in various brain regions during embryonic and early postnatal development. However, a rather dramatic downregulation of IRP mRNA expression was observed in these same brain regions by PND 10. It is tempting to speculate that this dramatic developmental change in IRP expression coincides with the rather substantial loss of neurons, which is known to occur via apoptosis during brain development (Raff et al., 1993). However, the relationship between IRP mRNA expression, its translation to protein, and functional protease activity are as yet unclear, and further work will be necessary to substantiate a role for IRP in normal brain development. Nonetheless, our data do demonstrate relatively high levels of IRP expression during early brain development.

Overexpression of IRP achieved by transfecting HeLa cells with IRP cDNA induces cell death and the characteristic internucleosomal DNA fragmentation, a typical feature of apoptosis. Nondepolarizing conditions, which are known to trigger the apoptotic cascade of cultured cerebellar granule neurons (D'Mello et al., 1993; Yan et al., 1994), induces overexpression of the IRP gene. The induction of IRP mRNA in cultured cerebellar granule neurons exposed to nondepolarizing conditions is robust and coincides with (precedes) cell death. Moreover, the expression of IRP mRNA occurs after the commitment point for apoptosis and can be prevented by high $\mathrm{K}^{+}$ (depolarizing conditions) before this commitment point. Significantly, using the same hybridization conditions, we could not detect the presence of ICE in cultured cerebellar granule neurons prepared from cultures exposed to HK or LK conditions. In addition, previous studies have shown that ICE or the ICH/Nedd 2 family of proteases are unable to cleave PARP into a $89 \mathrm{kDa}$ fragment (Lazebnik et al., 1995; Tewari et al., 1995), whereas cotransfection of ICE, Tx, Nedd2, and PARP suggest that these proteases generate a $31 \mathrm{kDa}$ fragment of PARP ( $\mathrm{Gu}$ et al., 1995). Finally, treatment of cultured cerebellar granule neurons exposed to nondepolarizing (LK) conditions with BDNF reduces IRP mRNA expression and attenuates cell death. Several previous experiments have demonstrated that ICE-related protease(s) can be autoactivated (autocleaved), suggesting that overexpression of IRP could contribute to autoactivation of its catalytic (protease) activity. Thus, activation of this cell death machinery may occur not only through post-translational activation of an ICE-like protease (via proteolytic processing of its precursor protein) but also by induced expression (increased transcription) of the protease gene itself, presumably leading to an increase in protease activity.

Taken together, our data suggest that transcriptional activation of CPP32 (or a closely related protease) is associated with the death of cultured cerebellar granule neurons induced by nondepolarizing culture conditions. We cannot, however, exclude the involvement of other ICE-like proteases in the death cascade of cultured cerebellar granule neurons.

\section{REFERENCES}

Altman J (1972) Postnatal development of the cerebellar cortex in the rat. 3. Maturation of the components of the granule layer. J Comp Neurol 145:465-513.

Cotman CW, Anderson AJ (1995) A potential role for apoptosis in neurodegeneration and Alzheimer's disease. Mol Neurobiol 10:19-45.

D'Mello SR, Gall C, Ciotti T, Calissono P (1993) Induction of apoptosis in cerebellar granule neurons by low potassium: inhibition by insulinlike growth factor I and cAMP. Proc Natl Acad Sci USA 90:10989-10993.

Fernandes-Alnemri T, Litwack G, Alnemri E (1995) CPP32, a novel human apoptotic protein with homology to Caenorhabditis elegans cell death protein CED-3 and mammalian interleukin- $\beta$-converting enzyme. J Biol Chem 269:30761-30764.

Flaws JA, Kugu K, Trbovich AM, DeSanti A, Tilly KI, Hirshfield AN, Tilly JL (1995) Interleukin-1 $\beta$-converting enzyme-related proteases (IRPs) and mammalian cell death: dissociation of IRP-induced oligonucleosomal endonuclease activity from morphological apoptosis in granulosa cells of the ovarian follicle. Endocrinology 136:5042-5053.

Galli C, Meucci O, Scorziella A, Werge T, Calissano P, Schettini G (1995) Apoptosis in cerebellar granule cells is blocked by high $\mathrm{KCl}$, forskolin, and IGF-1 through distinct mechanisms of action: the involvement of intracellular calcium and RNA synthesis. J Neurosci 12:1172-1179.

Gu Y, Sarnecki C, Aldape RA, Livingston DJ, Su M (1995) Cleavage of poly (ADP-ribose) polymerase by interleukin- $\beta$-converting enzyme and its homologs TX and Nedd-2. J Biol Chem 270:18715-18718.

Klein R, Nanduri V, Jing S, Lamballe F, Tapley P, Bryant S, CordonCardo C, Jones KR, Reichardt LF, Barbacid M (1991) The trk B tyrosine protein kinase is a receptor for brain-derived neurotrophic factor and neurotrophin-3. Cell 66:395-403.

Kozak M (1984) Compilation and analysis of sequences upstream from the translation start site in eukaryotic mRNAs. Nucleic Acids Res 12:857-872.

Kubo T, Nonomura T, Enokido Y, Hatanaka H (1995) Brain-derived neurotrophic factor (BDNF) can prevent apoptosis of rat cerebellar granule neurons in culture. Dev Brain Res 85:249-258.

Kuida K, Lippke JA, Ku G, Harding MW, Livingston DJ, Su MS, Flavell RA (1995) Altered cytokine export and apoptosis in mice deficient in interleukin-1 beta-converting enzyme. Science 267:2000-2003.

Kumar S, Kinoshita M, Noda M, Copeland NG, Jenkins NA (1994) Induction of apoptosis by mouse Nedd2 gene which encodes a protein similar to the product of Caenorhabditis elegans cell death gene ced-3 and mammalian IL- $1 \beta$-converting enzyme. Genes Dev 8:1613-1626.

LaFerla FM, Tinkle BT, Bieberich CJ, Haudenschild CC, Jay G (1995) The Alzheimer's A $\beta$ peptide induces neurodegeneration and apoptotic cell death in transgenic mice. Nat Genet 9:21-29.

Landis DM, Sidman RL (1978) Electron microscopic analysis of postnatal histogenesis in the cerebellar cortex of staggerer mutant mice. J Comp Neurol 179:831-863.

Lassmann H, Bancher C, Breitschopf H, Wegiel J, Bobinski M, Jellinger K, Wisniewski HM (1995) Cell death in Alzheimer's disease evaluated by DNA fragmentation in situ. Acta Neuropathol (Berl) 89:35-41.

Lazebnik YA, Kaufmann SH, Desnoyers S, Poirier GG, Earnshaw WC (1994) Cleavage of poly (ADP-ribose) polymerase by a protease with properties like ICE. Nature 371:346-347.

Li P, Allen H, Banerjee S, Franklin S, Herzog L, Johnston C, McDowell J, Paskind M, Rodman L, Salfeld J, Towne E, Tracey D, Wardwell S, Wei F, Wong W, Kamen R, Seshadri T (1995) Mice deficient in IL-1 $\beta$-converting enzyme are defective in production of mature IL-1 $\beta$ and resistant to endotoxic shock. Cell 80:401-411.

Marini AM, Paul SM (1992) N-methyl-D-aspartate receptor-mediated neuroprotection in cerebellar granule cells requires new RNA and protein synthesis. Proc Natl Acad Sci USA 89:6555-6559.

Miura M, Rotello R, Hartwieg E, Yuan J (1993) Induction of apoptosis in fibroblasts by IL- $1 \beta$-converting enzyme, a mammalian homolog of the C. elegans cell death gene ced-3. Cell 75:653-660.

Ni B, Rosteck Jr PR, Nadi NS, Paul SM (1994) Cloning and expression 
of a cDNA encoding a brain-specific $\mathrm{Na}^{+}$-dependent inorganic phosphate cotransporter. Proc Natl Acad Sci USA 91:5607-5611.

Ni B, Du Y, Wu X, DeHoff BS, Rosteck Jr PR, Paul SM (1996) Molecular cloning, expression, and chromosomal localization of a human brain-specific $\mathrm{Na}^{+}$-dependent inorganic phosphate cotransporter. J Neurochem 66:2227-2238.

Nicholson DW, Ali A, Thornberry NA, Vaillancourt JP, Ding CK, Gallant M, Gareau Y, Griffin PR, Labelle M, Lazebnik YA, Munday NA, Raju SM, Smulson ME, Yamin T, Yu V, Miller DK (1995) Identification and inhibition of the ICE/CED-3 protease necessary for mammalian apoptosis. Nature 376:37-43.

Raff MC, Barres BA, Burne JF, Coles HS Ishizaki Y, Jacobson MD
(1993) Programmed cell death and the control of cell survival: lessons from the nervous system. Science 262:695-700.

Tewari M, Quan LT, O'Rourke K, Desnoyers S, Zeng Z, Beidler DR, Poirier GG, Salvesen GS, Dixit VM (1995) Yama/CPP32 $\beta$, a mammalian homolog of CED-3, is a CrmA-inhibitable protease that cleaves the death substrate poly (ADP-ribose) polymerase. Cell 8:801-809.

Wood KA, Dipasquale B, Youle RJ (1993) In situ labeling of granule cells for apoptosis-associated DNA fragmentation reveals different mechanisms of cell loss in developing cerebellum. Neuron 11:621-632.

Yan G, Ni B, Weller M, Wood KA, Paul SM (1994) Depolarization or glutamate receptor activation blocks apoptotic cell death of cultured cerebellar granule neurons. Brain Res 656:43-51. 